$\mathrm{Cr} \cdot \mathrm{Ni}$ 基耐熱合全である $\mathrm{C}-0.1 \mathrm{~B}$ 合金の磨食量は，S-816 のそれの1/5，U-500の1/3.5であった。

乙かし, $\mathrm{A}$ 合金 $(38 \mathrm{Cr}, 2 \mathrm{Al}, 4.5 \mathrm{Mo}$ 残部 $\mathrm{Ni}$ )の臂食量 は C-0.1B 合金の 2 倍以上であり，本高 $\mathrm{Cr} \cdot \mathrm{Ni}$ 基合金で む灰满食抵抗に刘する合金組成の配堅が重要であることが 判明した。
本笑匼の遂行につき東芝総会研究开栗原和信，告田宏 両工惟に全面的な御指導をいただき，河合まよび野老雨氏 に衡支援をいただいた。さらに然䃥試㩆ではタービン事業 部昍足 純工博に郝協力を的䫝いしたので謝意を述べる次 第です.

\title{
Fe-Zn 拡散対における金属間化合物相の形成について
}

\author{
大西正已* 若松良德* 佐ふ木輝憲**
}

\begin{abstract}
Masami Onishi, Yoshinori Wakamatsu and Terunori Sasaki : Formation Kinetics of Intermetallic Compounds in Fe-Zn Diffusion Couples. The iron-electrodeposited zinc diffusion couples were annealed at temperatures from 240 to $320^{\circ} \mathrm{C}$. In the diffusion zone intermetallic compounds appear in the order of the $\zeta, \delta_{1}$ and $\Gamma$ phases. Kirkendall markers exist always at the interface between the $\zeta$ phase and $\mathrm{Zn}$. This pronounced Kirkendall effect means that there is a one-sided diffusion of $\mathrm{Zn}$ atoms by a vacancy mechanism.

The $\zeta_{s}$ phase which exists as a single phase in the diffusion zone at the initial annealing stage grows according to a parabolic rate law. The interface concentration of the $\zeta_{s}$ phase in contact with the iron couple half deviates about 2.4 at $\% \mathrm{Fe}$ to the Fe side from the boundary concentration on the Fe-rich side of the equilibrium $\zeta$ phase or from the stoichiometric composition of FeZn $\mathrm{n}_{13}$ $(7.1$ at $\% \mathrm{Fe})$. It is suggested that the deviation is caused by the formation of vacancies on the zinc atom sites and the vacancies contribute to the one-sided diffusion of zinc atoms. Dependence of the diffusion coefficients in the $\zeta_{s}$ phase on temperature is given by the following equation:

$$
D_{\zeta s}=4.25 \times 10^{-3} \exp (-17900 / R T) \text {. }
$$$$
\text { (Received January 29, 1973) }
$$

\section{I. 緒言}

前報(1) では $\mathrm{Fe}$ 粉と $\mathrm{Zn}$ 粉の琨合目粉体を $300^{\circ} \mathrm{C}$ 前後 の比較的低澏で加熱することによって，Fe-Zn 系平衡状 態图で浔められる3 種類の金属間化合物相が一定の慣序に したがって形成されることを明らかにした，特に前報で は，正粉体の膨張至化合物相の执散生成と関連つけて追求 した絬果，Znが化合物相内へ一力的に搪散流入するため， 化合物相に援するZn 領域にいわ功るカーケンドール空㗂

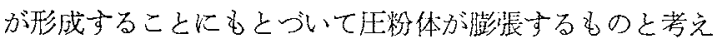
た.しかしながら，空隐の形成によって化合物相と $\mathrm{Zn}$ と

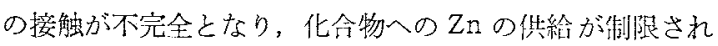
るので，压粉体で求めた化含物相の形成順序が半無限固体 㧓散対にそのまま適用できるか否かは明らかでなかった。

$\mathrm{Fe}-\mathrm{Zn}$ 系はもちろんのこと，他の 2 元系に扟いても現 在までに挫散対内の相形成順序に直接触れた研究は見受け られないようであり，相形成顺序は反応拡散全般の立場か らも興怢ある問題である。本研究では，FeにZnの電気

* 九州工業大学金属加工学教室 (Department of Metallurgy, The Kyushu Institute of Technology, Kita-Kyushu)

** 九州工業大学大学院(Graduate School, The Kyushu Institute of Technology, Kita-Kyushu)
メッキを施した試料を主たる拡散対とし，半想限固体の条

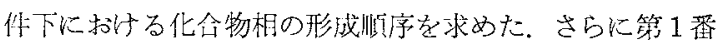
目に形成される 種類の金属間化合物相とともに平衡状態図で㤎められる $\alpha \mathrm{Fe}(\mathrm{Zn}$ 周溶)およびク $\mathrm{Zn}$ ( Fe 固浴) 相が㧓散対内に存在 するか否かについて教察した。

\section{II. 実験方 法}

純 Fe 試料には既報の縕成(2)のbのを使用し，平均結晶

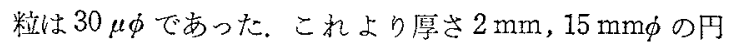
板を切り出し，表面をバフ价研燓に仕上げてから電気 Zn メッキを施した。メッキ浴組威は $1 \mathrm{~L}$ の溶液中に $\mathrm{H}_{2} \mathrm{SO}_{4}$ $360 \mathrm{~g}, \mathrm{NH}_{4} \mathrm{Cl} 30 \mathrm{~g}, \mathrm{NaC}_{2} \mathrm{HO}_{2} \cdot 3 \mathrm{H}_{2} \mathrm{O} 15 \mathrm{~g}$ であり, 浴温は $20^{\circ} \mathrm{C}$, 陽極にはPtを使用した。電流密度 $2 \mathrm{~A} / \mathrm{dm}^{2}, 24 \mathrm{hr}$

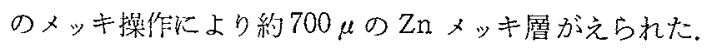

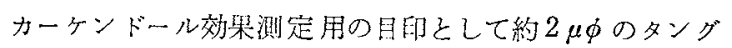
ンテン粉末を使用し，電気メッキに先だち， $\mathrm{Fe}$ 試料表面 にタングステン粉末を塗椎する，その後，Fe試料の上下

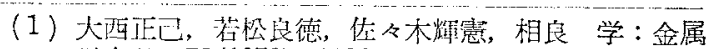
学金结, 36(1972), 1196.

（2）大西正已，若松是德，福本弘一，相度 学：金属学 全隹, 36(1972), 150. 
にダイス鋼板を重社合せて約 $10 \mathrm{~kg} / \mathrm{cm}^{2}$ の荷重を加觉るこ とにより，タングステン粉术を鉄試料中に埋没さ孙てから

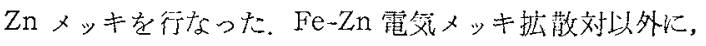
Feおよび Znがともに板材から成る桩散対を使用した。

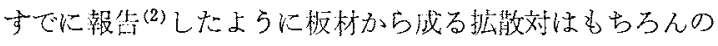

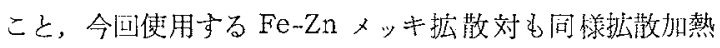
の祭沉外からクランプなどで桩散対を拘束しない限り，拡 散によって形成した化合物相亡Zn界面て磪实に㔀離が生

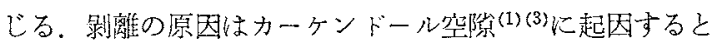

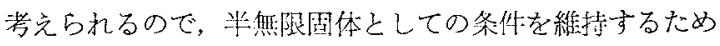
には空覍をつぶす程度の外打を昖散対に加えなければなら ない.この目的のため本実駼では既報は2゙準してクランプ 法を採用した。またX線マイクロアナライザーによる濃度 分析法もすべて既報に準じた。なお挑散加熱㳀度は240〜

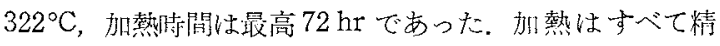
製アルゴン中で行ない，温度は常に所定温度 $\pm 1^{\circ} \mathrm{C}$ 以内に 制御した。

\section{III. 実 験 結 果}

\section{1．金属間化合物相の形成順序}

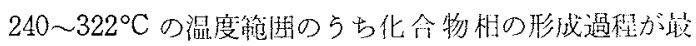

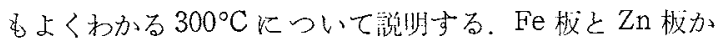

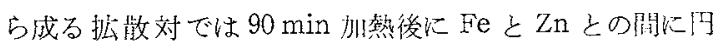
錐状鼠の出現が見受忛ら礼る。Photo.1はFe板とZn 板 から成る搪散対を $300^{\circ} \mathrm{C} て ゙ 3 \mathrm{hr}$ 加熱した場全の組織であ $\eta$ ，写真上部の $\mathrm{Zn}$ と下部の $\mathrm{Fe}$ との間比来将状化合物相 が存在する，崡牙状化合物相は阿錐状唱が成長し，一部が 左右に連䋨することによって形成される，との後加熱在繶 けると，来牙状晶は它全に連結し層状に発速する。他方 $\mathrm{Fe}-\mathrm{Zn}$ メッキ払散対では $300^{\circ} \mathrm{C}, 30 \mathrm{~min}$ 加熱後において む約 $10 \mu$ の層状化合物相が認められるので,メッキ拡散 対のよ5に $\mathrm{Fe}$ と $\mathrm{n}$ との接触が良好な場合には，はじめ

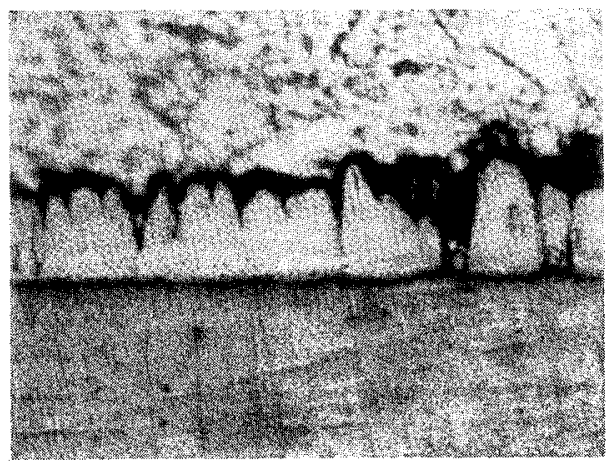

Photo.1 Microphotograph of the conical $\zeta$ phase formed at the interface between the iron and zinc plates. Annealing at $300^{\circ} \mathrm{C}$ for $3 \mathrm{hr}(\times 800 \times 5 / 6)$

(3) A.A.Hershmann and N.D.Neemuchwala : Brit. Corrosion J., $1(1965 / 1966), 51$.
から層状化合物相が出現し，接触が不完全な場合にのみ円 鐎状あるいは歯牙状化合物相が出現することがかかる。化 合物相の形成過程を調べるには，はじめから層状化合物相 の出現する Fe-Znメッキ㧓散效の泀らが適するので，以 下に Fe-Znメッキ抬散対について説明する。

Photo.2 は Fe-Zn×ッキ挫散対を $300^{\circ} \mathrm{C}$ で㮔々なる將 闑加熱したときの化会物相の成長過程を示している。立ず $1 \mathrm{hr}$ J熱後の Photo.2(a)では上部の Zn と下部の Fe との 間炕層状の単一化合物相が存在する. $5 \mathrm{hr}$ 加熱後の Photo. 2 (b)では，化合物相中の $\mathrm{Fe}$ 側に第 2 番目の化合物相の出 现が徵祭される。 その後，Photo.2(c)を経て，第2 番目に 江現した化会物相は完全に左右に連絬して層状となる。こ の段階以降化会物相は 3 相として観察される.

Fig.1はPhoto.2に示した種々なる加熱段階における化 合物相を Fe から Zn 側晌って走查したときの E.P.M.

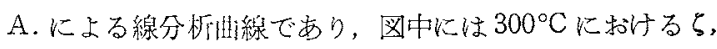

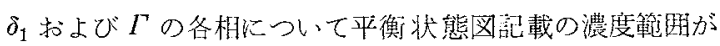

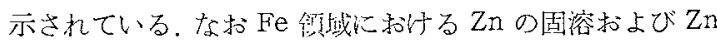
領域比故る Fe の国溶はE.P.M.A.に上り検出できな かったのでこれらの領㖪における線分析曲線はずへて省 略されている。まずA曲線は Photo.2(a)に示した単一化

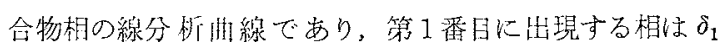
かららまでの連綾した縕成を有する，前報(1)で述べた $\mathrm{Fe}-\mathrm{Zn}$ 粉木本の混合佂粉体では，まずはじめに形成される化 合物相はら相であり，その分析曲線はA曲線之同形であ るから, Photo.1(a)の単一化合物相は ら相であることが わかる。 B怙よびC曲線はそれぞれPhoto.2(c)の単相领 域と 2 相領域で求められたものである。B目線では淟度飛 躍が垫められず曲線が逨続しているが，C曲線では团線形 が不連繶となり，第2 番目に出現する $\delta_{1}$ 相の存在が明ら か炕なる。

Photo.2(e)によれば化合物相は 3 相存在するようではあ るが，Photo.2(e)を走查した D 击線では $\delta_{1}$ 相と Fe との

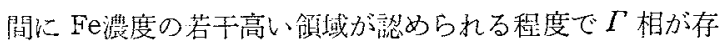
在するとは考えられない，さらに拡散時間の長い Photo. 2 (f)を走查した E曲線ではじめて $\Gamma$ 相が見受けられる。

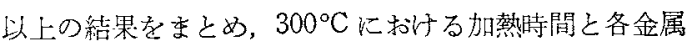
間化合物相中の Fe 濃度との関保を Fig.2 に示与，短時間

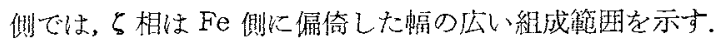
その後 $\delta_{1}$ 相が $\zeta$ 相を分断する形で形成される之, Zn 側の $\zeta$ 相は平衡絧成を示し， $\mathrm{Fe}$ 側の $\zeta$ 相は平衡 $\delta_{1}$ 相の $\mathrm{Fe}$ 側 限界濃度を萑干上迥る糺成を示す。ここで Fe 側に接した らをら゙と称することにすれば，その後加熱恃間を延長す

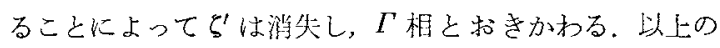
ように Fe-Zn 菜半無限国体拡散対では，まずはじめに 相，続いて $\delta_{1}$ 相，最後に $\Gamma$ 相が形成されることになる。

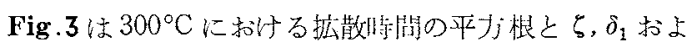
び「の各相幅および全相の合計幅との関係を示したもの 


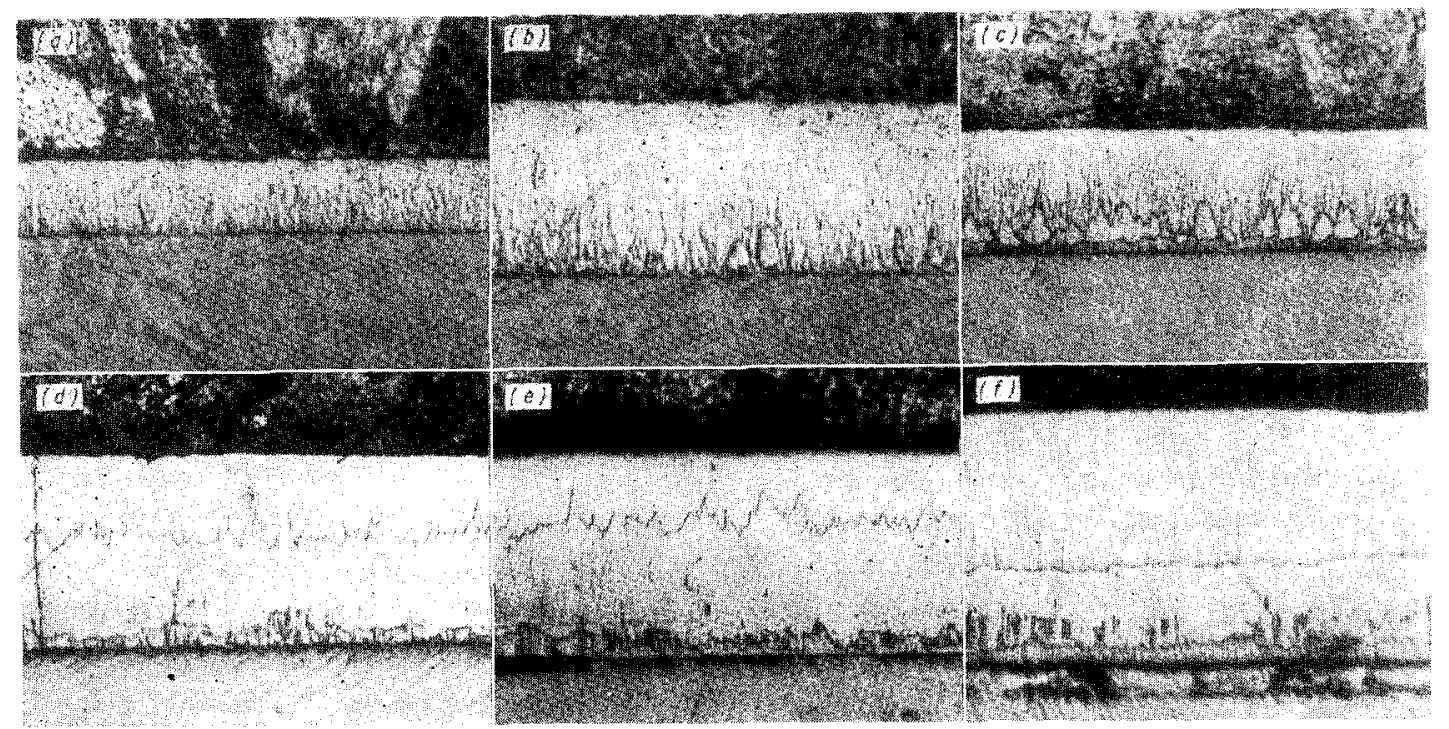

Photo.2 Microphotographs of Fe-electrodeposited $\mathrm{Zn}$ diffusion couples annealed at $300^{\circ} \mathrm{C}$ for various periods of time
(a) $1 \mathrm{hr}(\times 800 \times 2 / 3)$
(b) $5 \mathrm{hr}(\times 800 \times 2 / 3)$, (c) $9 \mathrm{hr}(\times 600 \times 2 / 3)$,
(d) $16 \mathrm{hr}(\times 400 \times 2 / 3)$,
(e) $25 \mathrm{hr}(\times 400 \times 2 / 3)$, (f) $40 \mathrm{hr}(\times 400 \times 2 / 3)$

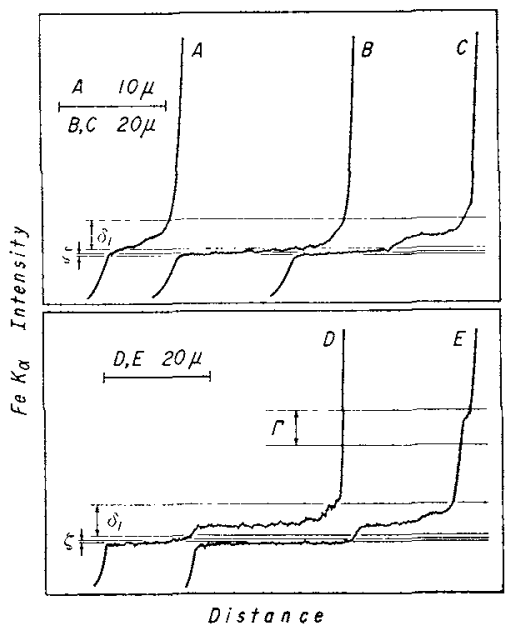

Fig.1 E.P.M.A.line analysis for Fe-electrodeposited $\mathrm{Zn}$ diffusion couples annealed at $300^{\circ} \mathrm{C}$ for various periods of time

$\mathrm{A}: 1 \mathrm{hr}, \mathrm{B}$ and $\mathrm{C}: 9 \mathrm{hr}, \mathrm{D}: 25 \mathrm{hr}, \mathrm{E}: 40 \mathrm{hr}$

である，加熱の初期に単相として存在するら相は放物線

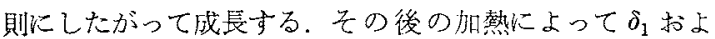

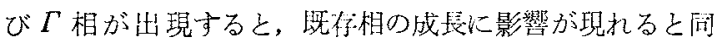
時に全相の合計幅も複雑に変化する，全相の合計幅および 既存相に対する $\delta_{1}$ 相の影響が大きいのは，第 1 に $\delta_{1}$ 相の 成長速度が大なること，第 2 に $\delta_{1}$ 相洁現以前の $\zeta$ - Fe 界面 はFe 側に移動していたのに対して， $\delta_{1}$ 相形成によって新

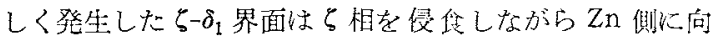
って移動するためである、な找進れて形成される $\delta_{1}$ および

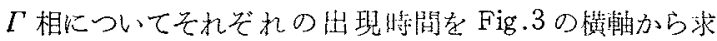

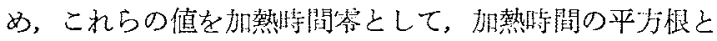

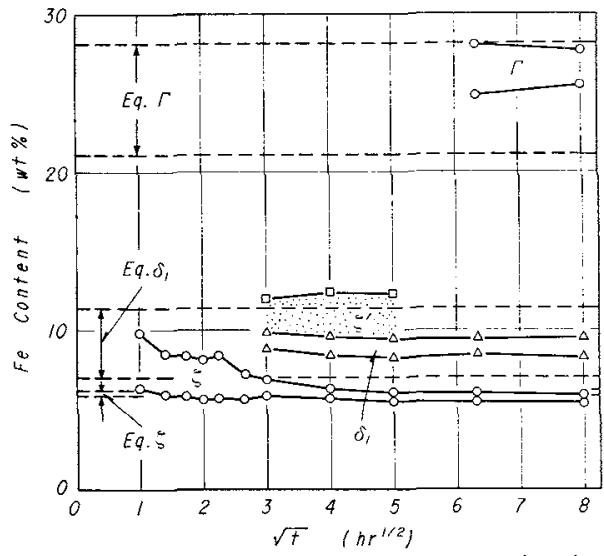

Fig.2 Time dependence of Fe concentration in the $\zeta, \delta_{1}$ and $\Gamma$ intermetallic phase layers vs. square root of annealing time at $300^{\circ} \mathrm{C}$. Feelectrodeposited $\mathrm{Zn}$ diffusion couples

各相幅との関係を別にえがき直すと放物線則が成立する。 またFig.3には示していないが，長㨍間の加熱後に $\delta_{1}$ 相 が急成長しはじめる。この場合にる既存相および全相の全 計偪に再び影響が現れるのでここいらの問题については一 括して続報で述べることにする。

ここで加熱の初期に単相として存在するらを后斿とし，

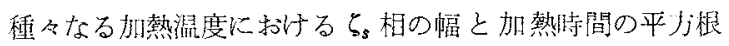
との関係をFig.4に示す。これより実駼を行なった温度 箸围でらは放物線則にしたがって成長することがわかる。

2. $\zeta_{s}$ 相の成長過程におけるカーケンドール効果と拡 散係数

Photo.3 は $280^{\circ} \mathrm{C}, 16 \mathrm{hr}$ 加熱後にお汁るタングステン 目印位置を示したものである。タングステン粉末が多量に 


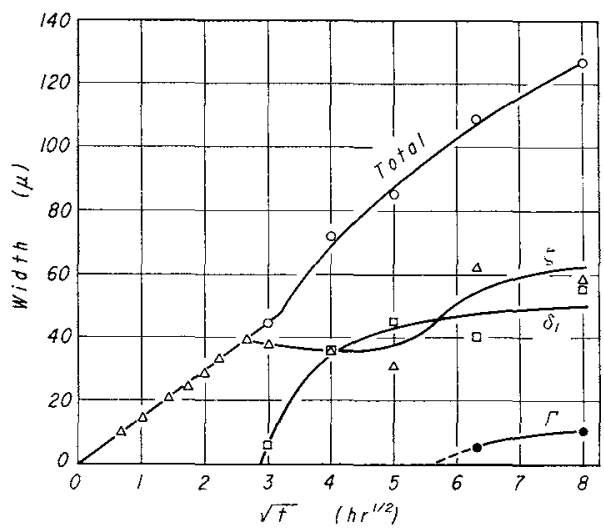

Fig.3 Width of the $\zeta, \delta_{1}$ and $\Gamma$ phase layers and of the total phase layers vs. square root of annealing time. Fe-electrodeposited $\mathrm{Zn}$ diffusion couples

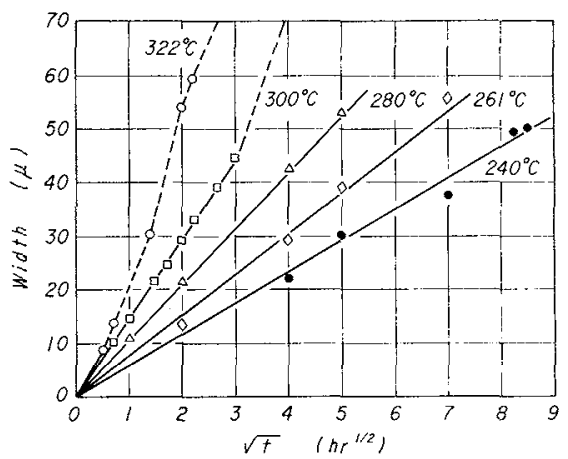

Fig.4 Width of the $\zeta_{s}$ phase layers formed at the initial stage of annealing vs. square root of annealing time. Fe-electrodeposited $\mathrm{Zn}$ diffusion couples

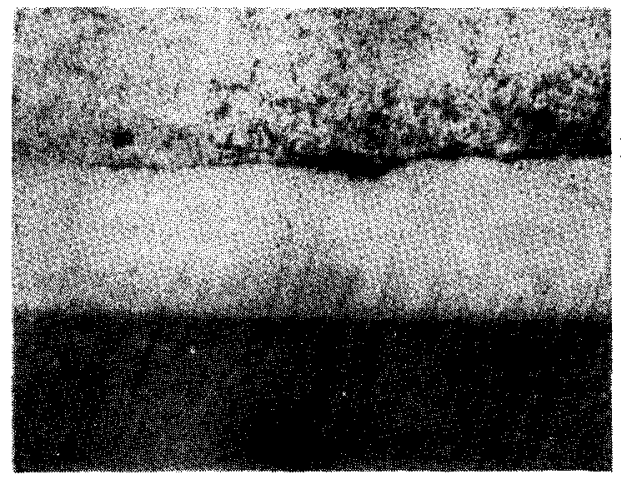

Zn

Marker

Photo.3 Microphotograph of the marker position in a Fe-electrodeposited $\mathrm{Zn}$ diffusion couple annealed at $280^{\circ} \mathrm{C}$ for $16 \mathrm{hr}$

$(\times 400 \times 5 / 6)$

存在する領域では搪散が阻害され，ら 相の幅が減少して いるが，目四は常火 $\zeta_{s}$ と $\mathrm{Zn}$ との間に标在する。

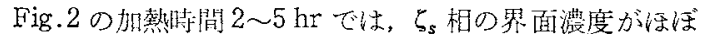

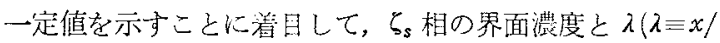
$\sqrt{t})$ と関係 Fig.5に示す，同㘠を光がくに祭して，

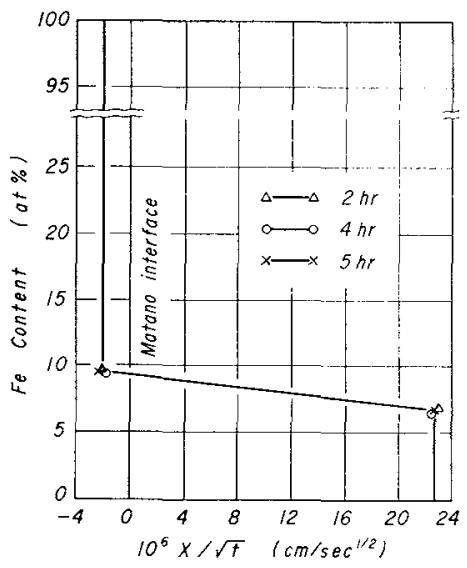

Fig. 5 Fe concentration vs. $\lambda\left(x / t^{1 / 2}\right)$ for $\mathrm{Fe}-$ electrodeposited $\mathrm{Zn}$ diffusion couples annealed at $300^{\circ} \mathrm{C}$

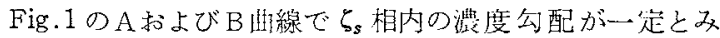
なされるので，らs相の $\mathrm{Fe}$ 濃度とえとの関係を直線で近 似した。 また前述のように，Fe 中への Zn の固溶および $\mathrm{Zn}$ 中への Fe の固浴が橹出されなかったので，ら

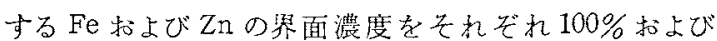

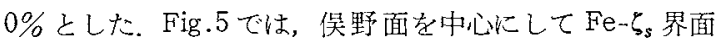
と $\zeta_{s}-Z n$ 界面がそれぞれ逆方向に移動し， $-\lambda_{Z_{\mathrm{n}}} / \lambda_{\mathrm{F}}$ が 11.3 となることがわかる. Table 1 は

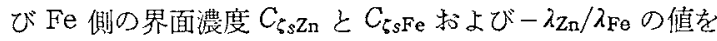
示したものであり，これより契跧を行なったすべての温度 でFig. 5 の形が成立し，また $-\lambda_{\mathrm{n}} / \lambda_{\mathrm{Fe}}$ は温度依存性を示 さずほほぼ一定であることがわかる。

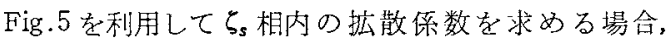
Heumann の方法(4) 使用することが可能であり，この方 法に上れば $\zeta_{s}$ 相内の平均的桩散係数 $D_{\zeta s}$ は (1) 式で示さ れる。

$$
D_{\zeta s}=-\frac{1}{2 t} \frac{W_{\zeta s}}{C_{\zeta_{s} \mathrm{Zn}}-C_{\zeta s \mathrm{Fe}}} \int_{0}^{C_{1 / 2}} x d x
$$

ここで $t$ は拡散時間， $W_{\zeta s}$ は $\zeta_{s}$ 相の幅, $C_{1 / 2}$ は $\zeta_{s}$ 相の 平均濃度 $1 / 2\left(C_{\xi_{s e}}+C_{\xi_{s} \mathrm{n} n}\right)$ である。

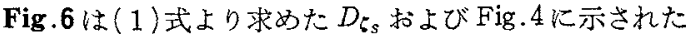
直線の勾配の 2 乗つまり $\left(W_{\xi s}\right)^{2} / t$ の温度依存性を示寸。こ れより $D_{\xi_{s}}$ と $\left(W_{\xi_{s}}\right)^{2} / t$ とが挍近した值を示すことがわか る.

Wagner(5) 2 元多相系の拡散について，個々の相内の 毛散係数が濃度に依存せず一定である場合を，境界条件の 異なる5種類に分けて昖散係数を求める方法を説明してい る.ここで $\zeta_{s}$ 相内の执散係数を一定とみなせば, Wagner による第 5 番目の方法にしたがって $D_{\text {s }}$ を求めることが 可能である。俣野面かららs相の $\mathrm{Fe}$ 側および $\mathrm{Zn}$ 側界面

(4) T.Heumann: Z.Phys.Chem., 201 (1952), 168.

(5) W.Jost: Diffusion in Solids, Liquids and Gassses. Academic Press, New York, (1960), 69. 
Table 1 Iron concentration at the $\zeta_{s}$ phase boundary $\left(C_{\xi s F e}, C_{\xi_{s} Z_{\mathrm{n}}}\right)$ and $-\lambda_{\mathrm{Zn}} / \lambda_{\mathrm{Fe}}$

\begin{tabular}{|c|c|c|c|c|c|c|c|c|}
\hline \multirow{2}{*}{$\begin{array}{c}\text { Temp. } \\
\left({ }^{\circ} \mathrm{C}\right)\end{array}$} & \multirow{2}{*}{$\begin{array}{l}\text { Time } \\
\text { (hr) }\end{array}$} & \multicolumn{3}{|c|}{$C($ at $\% \mathrm{Fe})$} & \multicolumn{3}{|c|}{$\lambda\left(10^{-6} \mathrm{~cm} / \mathrm{sec}^{1 / 2}\right)$} & \multirow{2}{*}{$-\lambda_{\mathrm{Zn}} / \lambda_{\mathrm{Fe}}$} \\
\hline & & $C_{6 s}$ & & $C_{s s \mathrm{Zn}}$ & $-\lambda_{\mathrm{F} \theta}$ & $\lambda_{z_{n}}$ & & \\
\hline 240 & $\begin{array}{l}16 \\
25 \\
64 \\
72.5\end{array}$ & $\left.\begin{array}{r}10.0 \\
9.8 \\
9.4 \\
9.6\end{array}\right\}$ & 9.7 & $\left.\begin{array}{l}6.7 \\
6.5 \\
6.3 \\
6.4\end{array}\right\} 6.5$ & $\left.\begin{array}{l}0.81 \\
0.83 \\
0.81 \\
0.79\end{array}\right\} 0.81$ & $\left.\begin{array}{l}8.88 \\
9.30 \\
9.46 \\
9.02\end{array}\right\}$ & 9.17 & 11.3 \\
\hline 261 & $\begin{array}{l}16 \\
25\end{array}$ & $\left.\begin{array}{l}8.8 \\
9.5\end{array}\right\}$ & 9.2 & $\left.\begin{array}{l}6.4 \\
6.4\end{array}\right\} 6.4$ & $\left.\begin{array}{l}0.92 \\
1.03\end{array}\right\} 0.98$ & $\left.\begin{array}{l}11.13 \\
11.93\end{array}\right\}$ & 11.53 & 11.7 \\
\hline 280.5 & $\begin{array}{r}4 \\
16 \\
25\end{array}$ & $\left.\begin{array}{l}9.5 \\
8.9 \\
8.6\end{array}\right\}$ & 9.0 & $\left.\begin{array}{l}6.9 \\
6.1 \\
6.4\end{array}\right\} 6.5$ & $\left.\begin{array}{l}1.47 \\
1.33 \\
1.33\end{array}\right\} 1.38$ & $\left.\begin{array}{l}16.42 \\
16.38 \\
16.33\end{array}\right\}$ & 16.38 & 11.8 \\
\hline 300 & $\begin{array}{l}2 \\
3 \\
4 \\
5\end{array}$ & $\left.\begin{array}{l}9.8 \\
9.6 \\
9.4 \\
9.7\end{array}\right\}$ & 9.6 & $\left.\begin{array}{l}6.8 \\
6.7 \\
6.5 \\
6.6\end{array}\right\} 6.7$ & $\left.\begin{array}{l}2.07 \\
1.91 \\
1.93 \\
2.01\end{array}\right\} 1.98$ & $\left.\begin{array}{l}22.85 \\
21.54 \\
22.42 \\
22.69\end{array}\right\}$ & 22.38 & 11.3 \\
\hline 322 & $\begin{array}{l}0.5 \\
1\end{array}$ & $\left.\begin{array}{r}10.3 \\
9.8\end{array}\right\}$ & 10.0 & $\left.\begin{array}{l}6.5 \\
6.4\end{array}\right\} 6.5$ & $\left.\begin{array}{l}3.03 \\
2.98\end{array}\right\} 3.01$ & $\left.\begin{array}{l}33.02 \\
33.83\end{array}\right\}$ & 33.43 & 11.1 \\
\hline
\end{tabular}

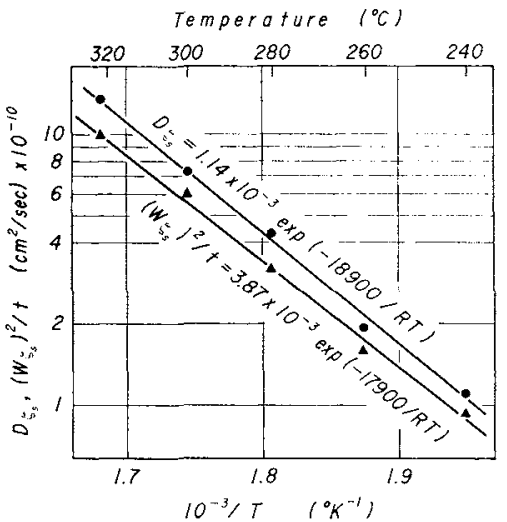

Fig.6 Arrhenius plots of $D_{\zeta s}$ and $\left(W_{\zeta s}\right)^{2} / t$. Feelectrodeposited $Z n$ diffusion couples

までの距離をそれぞれー の関保から(2)拉よび(3)式が成立する.

$$
\begin{aligned}
-\xi_{\mathrm{Fe}} / \sqrt{t} & =-\lambda_{\mathrm{Fe}}=-2 \gamma_{\mathrm{Fe}} \sqrt{ } D_{\zeta s} \\
\xi_{\mathrm{Zn} / \sqrt{t}} & =\lambda_{\mathrm{Zn}}=2 \gamma_{\mathrm{Zn}} \sqrt{ } D_{\zeta s}^{-}
\end{aligned}
$$

ここで $\gamma_{\mathrm{Fe}}$ および $\gamma_{\mathrm{Zn}}$ は常数であり（2)および(3)式 からら 相の成長係数の 2 乗は (4)式で示される.

$$
\frac{\left(W_{\zeta s}\right)^{2}}{t}=4\left(\gamma_{\mathrm{Zn}}-\gamma_{\mathrm{Fe}}\right)^{2} D_{\xi s}
$$

$\gamma_{\mathrm{Zn}}$ および $\gamma_{\mathrm{Fe}}$ は界面㳻度によって(5)拉よび(6)式で 示される。

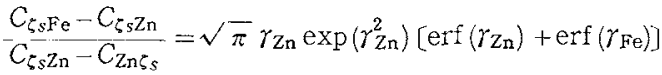

$\frac{C_{\zeta s \mathrm{Fe}}-C_{\zeta s \mathrm{Zn}}}{C_{\mathrm{Fe} \zeta \mathrm{s}}-C_{\zeta s \mathrm{Fe}}}=\sqrt{\pi} \gamma_{\mathrm{Fe}} \exp \left(\gamma_{\mathrm{Fe}}^{2}\right)\left[\operatorname{erf}\left(\gamma_{\mathrm{Zn}}\right)+\operatorname{erf}\left(\gamma_{\mathrm{Fe}}\right)\right]$

(5)および(6)式の左逝は Table 1 から求めら扎るので, $\gamma_{Z_{\mathbf{n}}}$ と $\gamma_{\mathrm{Fe}}$ 老計算しらる. 九州大学大型計算嘰(FACOM 230-60)の使用に上り求めた $\gamma_{\mathrm{Zn}}$ と $\gamma_{\mathrm{Fe}}$ の值范 Table 2 に 示す。同表では $\gamma_{Z \mathbf{n}}$ と $\gamma_{\mathrm{Fe}}$ の值を(4)式に代入して求めた $D_{\zeta_{s}}$ を $D_{W}$ として Heumann 汰による $D_{H}$ と比較してい る。雨者はよく一致している。

2 元多相系の拡散で，一つの中間相内の拡散係数法通常 アーレニウス型の温度低存性を示す. $W^{2} / t$ もまた同形式 の灄度依存性を示すことがしばしば報告されている。Dが 一定であれば(4)式の形は一般に成立するので， $W^{2} / t$ が 上記の温度依存性を示すならば， $\left(\gamma_{1}-\gamma_{2}\right)^{2}$ が常数でない

\begin{tabular}{|c|c|c|c|c|c|c|}
\hline \multirow{2}{*}{$\begin{array}{l}\text { Temp. } \\
\left({ }^{\circ} \mathrm{C}\right)\end{array}$} & \multirow{2}{*}{$-\gamma_{\mathrm{FB}}$} & \multirow{2}{*}{$\gamma_{\mathrm{Zn}}$} & \multirow{2}{*}{$4\left(\gamma_{Z \mathbf{n}}-\gamma_{F \theta}\right)^{2}$} & \multicolumn{3}{|c|}{$\left(W_{s s}\right)^{2} / t, D_{\zeta s}\left(10^{-10} \mathrm{~cm}^{2} / \mathrm{sec}\right)$} \\
\hline & & & & $\left(W_{s s}\right)^{2} / t$ & $D_{H}$ & $D_{W}$ \\
\hline $\begin{array}{l}240 \\
261 \\
280.5 \\
300 \\
322\end{array}$ & $\begin{array}{l}0.039 \\
0.035 \\
0.033 \\
0.037 \\
0.041\end{array}$ & $\begin{array}{l}0.445 \\
0.418 \\
0.396 \\
0.419 \\
0.460\end{array}$ & $\begin{array}{l}0.937 \\
0.821 \\
0.736 \\
0.832 \\
1.004\end{array}$ & $\begin{array}{l}0.931 \\
1.56 \\
3.16 \\
6.00 \\
9.82\end{array}$ & $\begin{array}{c}1.10 \\
1.91 \\
4.31 \\
7.28 \\
13.5\end{array}$ & $\begin{array}{l}0.994 \\
1.90 \\
4.29 \\
7.21 \\
9.78\end{array}$ \\
\hline \multicolumn{4}{|c|}{ Activation energy $(\mathrm{cal} / \mathrm{mol})$} & 17900 & 18900 & 17900 \\
\hline \multicolumn{4}{|c|}{ Frequency factor $\left(10^{-3} \mathrm{~cm}^{2} / \mathrm{sec}\right)$} & 3.87 & 11.4 & 4.25 \\
\hline
\end{tabular}
かざり $\left(r_{1}-\gamma_{2}\right)^{2}$ むまたフーレニウス武にしたがらものと

Table 2 Values of $\left(W_{s_{s}}\right)^{2} / t, \gamma_{F_{\theta}}, \gamma_{\mathrm{Zn}}$ and $D_{\zeta s}$ 
考えることができる，船水执よび渡辺 ${ }^{(5)}$ は若干の 2 元多相 系の搪散実験饵おいて(4)式の形が成立することを示し， $W^{2} / t$ の活性化エネルギーとDのそ礼との差は $\left(r_{1}-r_{2}\right)^{2}$ の 活性化亲ルギーに深涪等しいことを明らかにした，本研 究では Table 2 に示したよらに $\left(W_{\xi s}\right)^{2} / t$ の活性化エネル ギーと前指数項とは $D_{W}$ のそれぞれにほば完全に一致す る. 事䒠, $4\left(\gamma_{\mathrm{Z}_{\mathbf{n}}}-\gamma_{\mathrm{Fe}}\right)^{2}$ は1飞近い值を示し， $\left(\gamma_{\mathrm{Z}_{\mathbf{n}}}-\gamma_{\mathrm{F} \theta}\right)^{2}$ は温度体存性を示さない。これは温度が異なっても相境界 濃度が不変であることを物諧る。

\section{IV. 考察}

$\mathrm{Fe}-\mathrm{Zn}$ 系平衡状態図には $\zeta, \delta_{1}$ および $\Gamma$ の 3 種類の金 属間化合物相以外に, Fe 側に $\alpha$ 固溶体， $\mathrm{Zn}$ 侧に $\eta$ 固溶 体が存在する. $300^{\circ} \mathrm{C}$ における $\alpha \mathrm{Fe}$ 中の $\mathrm{Zn}$ の固溶量は 約 2 at $(1.7 \mathrm{wt}) \% \mathrm{Zn}(7)$ であるに対して, $\eta \mathrm{Zn}$ 中の Fe 固

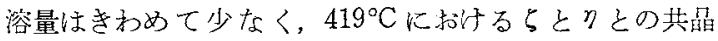
温度に执いてもク中の Fe 固溶量は0.009 at (0.008 wt)\% $\mathrm{Fe}^{(8)}$ に過ざない。

2 元系の反応拡散汇打いて純金属が固溶体を形成する過 程では考虑する必要はないが，金属间化合物相の形成過程

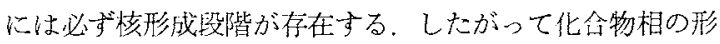
成顺序怯核形成の難易によって左右される可能性むある がここの問題を論じることはきわめて困難である。ここで は化合物相の形成順序を認めた上で，㤥形成について考鿉

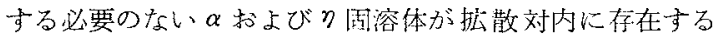
か有がついて考光てみる。

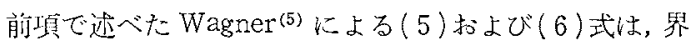

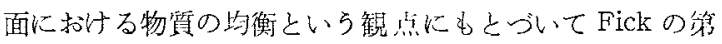
I捛よび第 2 法則から誘導されたものである。い びBの純金属から成る拡散対を加熱する場合，たとえば A-B 2 元系が共晶型の状態図を有し，Aおよび B 侧にそれ ぞれ $\alpha$ および $\beta$ で示される1次固溶体が存在すれば，桩 散加熱後の $c-x$ 曲線はFig.7(a)となる。.Wagner ${ }^{(5)}$ およ び Kidson ${ }^{(9)}$ にしたが党ば $\alpha-\beta$ 界面では $(7)$ 式が成立す る.

$$
\left(C_{\alpha \beta}-C_{\beta_{\alpha}}\right) d \xi=-d t\left\{\left(D \frac{\partial c}{\partial x}\right)_{\alpha \beta}-\left(D-\frac{\partial c}{\partial x}\right)_{\beta_{\alpha}}\right\}
$$

他方，BがAを固溶せず $\beta$ 固溶体が存在しない場合に は，Fig.7(b)のc-x曲線となり，界面では(8)式が成立 する。

$$
\left(C_{\alpha^{\beta}}-C_{\mathrm{A}}^{0}\right) d \xi=-d t\left(D \frac{\partial C}{\partial x}\right)_{\alpha^{\beta}}
$$

ここで $\beta$ 相中の固溶度がきわめて少なく， $C_{\beta_{\boldsymbol{\alpha}}} \approx C_{\mathrm{A}}^{0}$ であ れば $(D \partial c / \partial x)_{\beta_{\alpha}} \simeq 0$ となり $(7)$ 式は近似的に(8)式とな

（6）船水康宏, 渡辺膦也：金属学会誁演概要，(1972. 10), 212 .

(7) S.Budurov et a1. : Z. Metallk., 63 (1972) , 348.

(8) M.Hansen and K. Anderko: Constitution of Binary Alloys, McGraw-Hill, New York, (1959), 737.
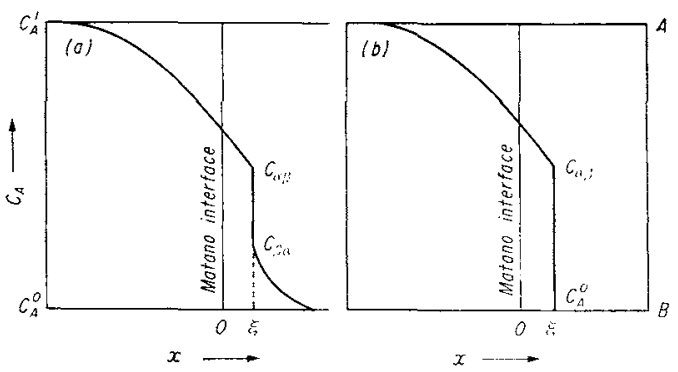

Fig.7 Schematic diffusion curves in A-B binary system

(a) Concentration in the $\alpha$ phase (primary solid solution of A) for $x<\xi$ and in the $\beta$ phase (primary solid solution of B) for $x>\xi$ (b) Concentration in the $\alpha$ phase (primary solid solution of $B)$ for $x<\xi$. Pure $B$ for $x>\xi$

る。なたBがAをかなり固溶することが平衡状態図で認め られていても $D_{\alpha \beta} \gg D_{\beta \alpha}$ であ机結果として $(D \cdot \partial c / \partial x)_{\alpha \beta}$ $\gg(D \cdot \partial c / \partial x)_{\beta a}$ が成立し, この場合拡散対には $\beta$ 固溶体

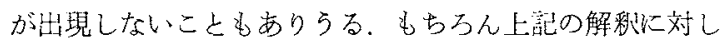
て苲密にはFick の法則が成立するための条件拉よび界面

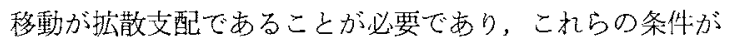
すべて满足されるならば（7)および（8)式の考光おは多相 系搪散のすべての界面で成立する。

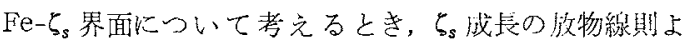

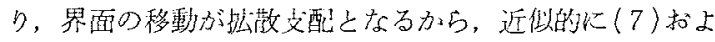
び(8)式の成立を情定することができる。ここで前報(1) と

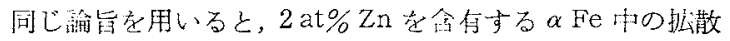
係数は $300^{\circ} \mathrm{C}$ に物いて $10^{-20} \mathrm{~cm}^{2} / \mathrm{sec}$ 亿なる。これに対して

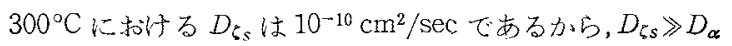
よりZnの国溶した $\alpha$ 相は出現しないことがわかる。また $\zeta s$ の成舆段階を過ぎ， 段階でも $\alpha$ 相は観察できなかったＩ相内の幽教係数が 明らかでないので，現段階では断走できないが，おてちく

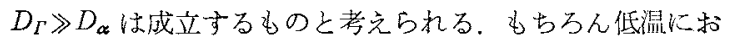
いては，体桩散よりも粒界桩散が優先するので，体拡散係 数だけで諭㼁を淮めることは良策ではないけれども，Zn の融点以下の洫度では $\alpha$ Fe の粒界でZn が検出される法 ぞ粒界拡散も顕著である委い。ただし $520^{\circ} \mathrm{C}$ 以上では事 情が異なり，たとえば $\mathrm{Fe}$ (固体) $\mathrm{Zn}$ (蒸気)の反応により $\Gamma$

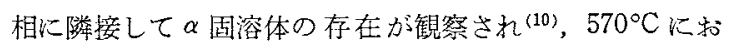

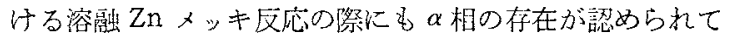
いる(11)。このよらな高温側では，粒界昖散をる含めた $\alpha$ 相内の㹡散係数が $\Gamma$ 相中のそれに比肩しらるようになり， ふたたび（7)式が成立するものと考えられる。

ク固溶体が存在寸るかしないかについてはク相叶の应

(9) G.V.Kidson : J.Nuc.Mat., 3 (1961), 21.

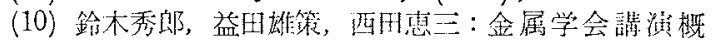
要, $(1971.4), 61$.

(11) W.N.Brown and J.Mackowiak : Corrosion Sci., 5 $(1965), 779$. 
散俰数が明らかでないので， $\alpha$ 固溶体について行なった諭

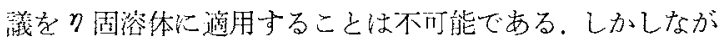
らク相中の Fe 固溶量が少ないことから自斯的心 (8) 式が 成立するので，少なくともZn 侧 $\zeta_{\mathrm{s}}$ 界面の移動速度に対 してはク国溶体の有惥はすったく関係がないといえる。

$\mathrm{Fe}$ (固体) $-\mathrm{Zn}$ (蒸気)の父応に上り，700 1000 $\mathrm{C}$ の渓度 䉇四で $\alpha \mathrm{Fe}$ に $\mathrm{Zn}$ が侵入する場合 ${ }^{(12)}$ ，および $520 \sim 600^{\circ} \mathrm{C}$

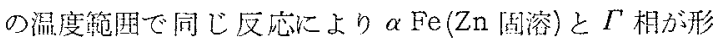

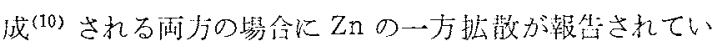
る.こ礼らの固体一気体搪做詨では目卵は常に固体表面に 存在与るのであるが，本研究のように固体閉の抵敬では

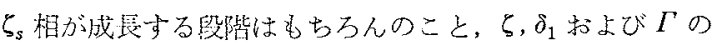
3 相がすべて成長する段階(2)でも目印は常に $\boldsymbol{s}_{\mathrm{s}}$ あるいは

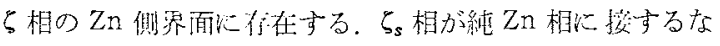

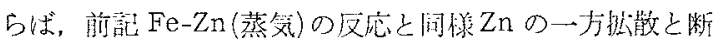

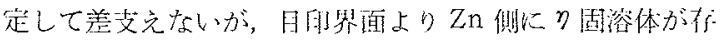

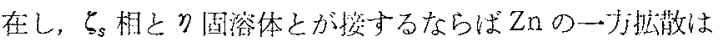

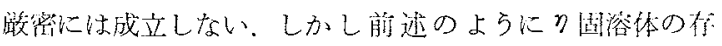
在の有無はら から，かりにり圆浴体が存在しても，目印界面を通り抜 ける Zn 原子数に対して逆方向值り抜ける Fe 原子数は 無視できることになり，近似的に一方㧙敬は成立する。

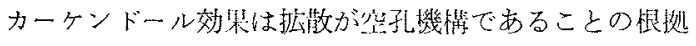
とみなされるから，Znの一方挫散であるならば，Zn 方向に進む等孔の流机が存在しなけ机ばならない。

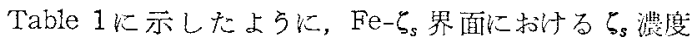
$C_{\zeta_{5} \mathrm{Fe}}$ は約 9.5 at \% Feとなり，ら相の化学量䑳的組成 $\mathrm{Fe} \mathrm{Zn}_{13}{ }^{(8)}$ より 2.4 at\% Fe だ汀 Fe 側倔倚している。偏

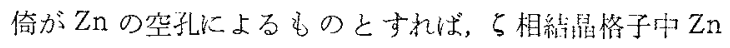
位德の $2.7 \%$ が空孔でらめられることになる。この場會の

（12）鉿木秀郎，益田雄策，囦田惠三：金属学会悲，36 (1972) , 509 .

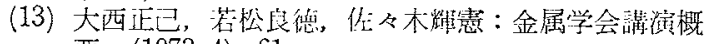
要, $(1973.4), 61$.
空孔は $\mathrm{Fe}-\zeta_{s}$ 算面で $\mathrm{Fe}$ 原子と Zn 原子とが

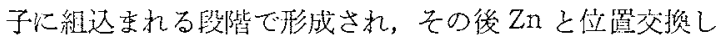

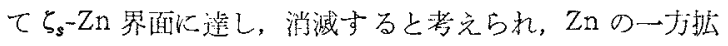
敬老説时することができる。ここでの空孔は熱活性による ものではなく、化学量浴的組成から偏倫によって生じるの で, 空孔形成のためのエンタルピーは㧾散の活性化エネル ギーに包含されない，らs相内の拡散の活性化エネルギーが $18000 \mathrm{cal} / \mathrm{mol}$ 程度の比較的小さい倠を示すのは上記の理 田にもとづくものと考えられる(13).

\section{V. 総 括}

Fe 板にZnの電参メッキを施した試料を主たる抬散対

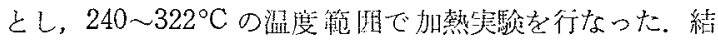
果は次の上うに要約される。

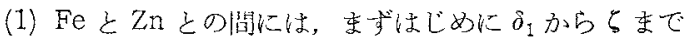

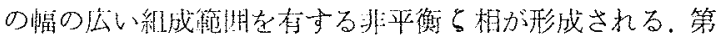
2 稩日の $\delta_{1}$ 相が形成されるとはじめに出現したら相は平

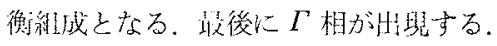

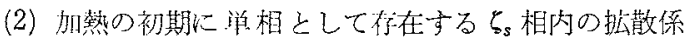
数をHeumann および Wagner のお法によって計算した

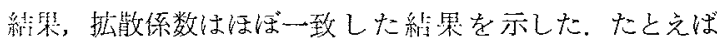
Wagner 法によれば $D_{\zeta_{s}}=4.25 \times 10^{-3} \exp (-17900 / R T)$ と

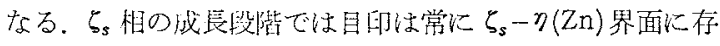
在し，空孔機棤による $\mathrm{Zn}$ の一方狇散であることがわかっ た.

(3) Fe-Zn 系平衡状態図の本研究温度範国化に, 前記 $\zeta, \delta_{1}$ 拉よび $\Gamma の 3$ 皬類の金属間化会物相以外江 $\alpha \mathrm{Fe}(\mathrm{Zn}$ 国溶)，》 $\mathrm{Zn}$ ( $\mathrm{Fe}$ 国溶) 相方不在する。本研究のあらゆる桩散 過程においても上部 2 種類の固溶体は镇察されなかった。 $\alpha$ 固溶体が出現しないことは説明できるが，ク固溶体の存 在の有無を明らかにすることは不可能であった。しかしク 固溶体が存在するか否かは，少なくともら相の成長には 影響を与克ないと考党て差支党ない。 